\title{
下肢の広範囲皮膚欠損に対する治療経験
}

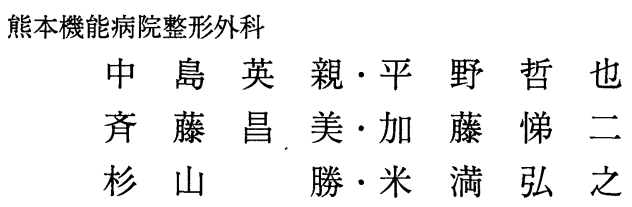

\section{Study of Flaps Used for Treating Wide Skin Defects of the Lower limb}

by

Hidechika Nakashima, Tetsuya Hirano, Masami Saito, Teizi Kato, Masaru Sugiyama and Hiroyuki Yomemitsu

Orthopedic Surgery Unit, Kumamoto Kinoh Hospital, Kumamoto, 860

Since May 1981, we have performed 25 cases cf Peroneal vascular island flap, 9 cases of free peroneal flap, 8 cases of free scapular flap, 9 cases of free groin flap and 5 cases of free latissimus dorsi flap. Our first selection for treating wide skin defects of the leg and foot is the peroneal vascular island flap which covers the exposed bone, vessels and nerves. In regard to free flaps, our first choice is to use a scapular flap.

The advantages of this flap are that the subcutaneous fat is thin, the branch of the circumflex scapular artery can be easily lccated, the vascular pedicle is long and vessel diameter is 1.2 to $2.0 \mathrm{~mm}$. In cases with wide skin defects from the knee to ankle joint we use a latissimus dorsi flap.

Key words : Peroneal flap (腓骨皮弁), Scapular flap (肩甲皮弁), Latissimus dorsi flap (広背筋皮弁)

\section{はじめに}

下肢の広範囲な皮虐欠損の治療は, 筋肉挫滅, 骨折 を合併していて困難な事が多い. 今回，私達は下肢特 に下腿，足部の皮虙欠損に対して，有茎の Peroneal flap 25 例, 遊離の Peroneal flap 19 例, Scapular flap 8 例, Groin flap 9 例, Latissimus dorsi flap 5 例を施行したので報告する.

\section{〈症例〉}

\section{有茎の Peroneal flap}

有茎の Peroneal flap（15 歳以下）は 9 例中男 性 7 例, 女性 2 例である. 年齢は 3 歳から 5 歳で平均 7.8 歳であった. flap の面積は $9 \mathrm{~cm} \times 3 \mathrm{~cm}$ から 20 $\mathrm{cm} \times 7 \mathrm{~cm}$ で, 平均 $12.8 \mathrm{~cm} \times 4.2 \mathrm{~cm}$ であった. 経過 観察期間は 1 年から 6 年 1 ケ月で平均 3 年 6 ケ月であっ
た. 有茎の Peroneal flap（16 歳以上）は 16 例中男 性 13 例，女性 3 例である. 年齢は 16 歳から 87 歳で 平均 44.8 歳であった. flap の面積は $10 \mathrm{~cm} \times 4 \mathrm{~cm}$ から $17 \mathrm{~cm} \times 7 \mathrm{~cm}$ で平均 $11.7 \mathrm{~cm} \times 4.4 \mathrm{~cm}$ であった. 5 例に血管柄付骨移植を同時に施行した. 経過観察期 間は 6 ケ月から 6 年で平均 2 年 11 ケ月であった.

遊離の Peroneal flap ${ }^{1)}$

19 症例中男性 14 例, 女性 5 例であり, 年齢は 9 歳 から 73 歳で平均 44.6 歳であった. flap の面積は, 10 $\mathrm{cm} \times 5.5 \mathrm{~cm}$ から $22 \mathrm{~cm} \times 8 \mathrm{~cm}$ で平均 $19 \mathrm{~cm} \times 6.8 \mathrm{~cm}$ であった．血管柄付骨移植は 1 例に施行した．経過観 察期間は 6 ケ月から 2 年 4 ケ月で平均 1 年 10 ケ月で あった。

Groin flap

9 症例で男性 6 例, 女性 3 例であり, 年齢は 15 歳 
から 50 歳で平均 34 歳であった. flap の面積は $8 \mathrm{~cm}$ $\times 5 \mathrm{~cm}$ から $19 \mathrm{~cm} \times 7 \mathrm{~cm}$ で, 平均 $16 \mathrm{~cm} \times 6 \mathrm{~cm}$ で あった. 血管柄付骨移植を 3 例に施行した. 経過観察 期間は 1 年から 11 年 6 ケ月で平均 7 年 1 ケ月であっ た.

Latissimus dorsi flap

5 症例中男性 4 例, 女性 1 例であり, 年齢は 13 歳 から 50 歳で, 平均 30 歳であった. flap の面積 $12 \mathrm{~cm}$ $\times 5 \mathrm{~cm}$ から $45 \mathrm{~cm} \times 16 \mathrm{~cm}$ で, 平均 $26.4 \mathrm{~cm} \times 9.8 \mathrm{~cm}$ であった. 経過観察期間は, 1 年 2 ケ月から 8 年で平 均 4 年 1 ケ月であった.

Flapの比較

表 I のようにそれぞれに特徴がある. 皮弁の挙上の 肢位は Peroneal flap では腹臥位, Scapular flap では側臥位としている．解剖学的血管走行では Peroneal flap は 44 例中 3 例に異常を認めた. これらは flapへの血管が細くて利用できなかったり，挙上部 の皮弁へ血管が入っていなかった. Scapular flap は 8 例と共に血管の解剖学的異常はなかった. 動脈径 はScapular flap と Latissimua dorsi flap が大 きく, 血管茎も長くとれた. 皮弁の大きさは Scapular flap で最大 $22 \mathrm{~cm} \times 8 \mathrm{~cm}$, Latissimus dorsi flap で $45 \mathrm{~cm} \times 16 \mathrm{~cm}$ と大きな皮弁がとれ， donor 側 は直接縫合できた. 血管柄付骨移植を同時に施行した のは, Peroneal flap, Groin flap, Scapular flap であった，有茎の flap は安全性が高く 87 歳の高年齢 にも用いられた。

\section{結果および考察}

表 Пのような治療法でflap を用いている，遊離血

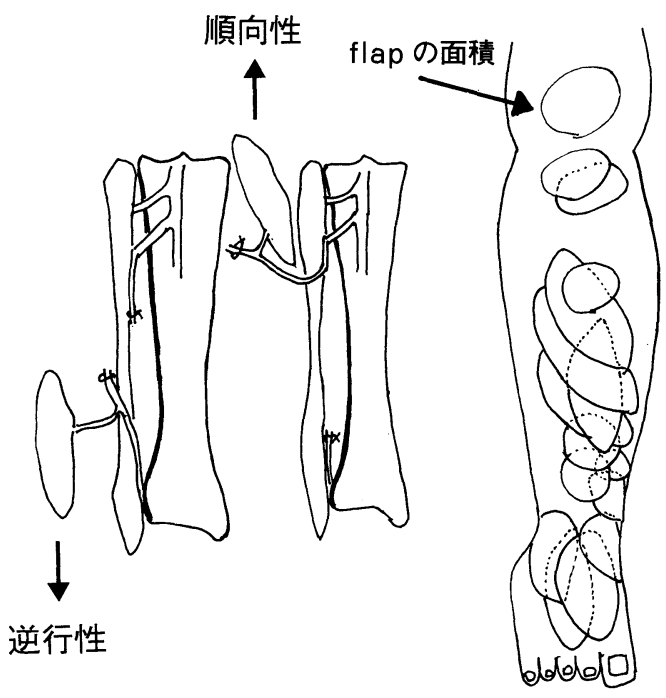

図 I 有茎 Peroneal flap の利用部位

表 II 下腿・足部の広範囲皮虚欠損の治療

1. Rotation flap 等, 局所皮弁が利用できないとき, 有茎の Peroneal flap で骨・神経・血管の露出部 を被い, 他の皮膚欠損部は全層植皮, 又は, 分層 植皮をしている。

2. 有茎の Peroneal flapが利用できないとき, 広範 囲な皮虐欠損には, 遊離の Scapular flap を第一 選択としている。

3. 骨欠損又は，偽関節を伴う皮用欠損は血管柄付骨 付きの Peroneal flap を利用する. 骨欠損が少な いときは, 血管柄付骨付き Scapular flap 又は, 血管柄付骨付 Groin flap も適応がある.

4.下腿全体におよぶ皮膚欠損には, Latissimus dorsi flapが最も適応と思われる.

表 I 下腿・足部に用いた皮弁の比較

\begin{tabular}{|c|c|c|c|c|c|}
\hline & $\begin{array}{c}\text { Peroneal flap } \\
\text { (有茎) }\end{array}$ & $\begin{array}{l}\text { Peroneal flap } \\
\text { (遊離) }\end{array}$ & Scapular flap & Groin flap & $\begin{array}{c}\text { Latissimus } \\
\text { dorsi flap }\end{array}$ \\
\hline 皮弁挙上肢位 & \multicolumn{2}{|c|}{ 腹臥位 } & 側臥位 & 仰臥位 & 側臥位 \\
\hline 解剖学的走行異常 & \multicolumn{2}{|c|}{$3 / 44$ 例 } & $0 / 8$ 例 & $1 / 9$ 例 & $0 / 5$ 例 \\
\hline 動脈径 & \multicolumn{2}{|c|}{$1.0 \sim 2.2 \mathrm{~mm}$} & $1.2 \sim 2.0 \mathrm{~mm}$ & $1.0 \sim 2.0 \mathrm{~mm}$ & $1.5 \sim 3.0 \mathrm{~mm}$ \\
\hline 皮弁挙上 & \multicolumn{2}{|l|}{ 容 } & 非常に容易 & 容 易 & 非常に容易 \\
\hline $\begin{array}{c}\text { ドナー側の } \\
\text { 直接綘縮の面積 }\end{array}$ & $\begin{array}{c}10 \times 4 \mathrm{~cm} \\
\sim 17 \times 7 \mathrm{~cm}\end{array}$ & $\begin{array}{c}4 \times 2 \mathrm{~cm} \\
\sim 21 \times 7 \mathrm{~cm}\end{array}$ & $\begin{array}{l}10 \times 5.5 \mathrm{~cm} \\
\sim 22 \times 8 \mathrm{~cm}\end{array}$ & $\begin{array}{c}8 \times 5 \mathrm{~cm} \\
\sim 19 \times 7 \mathrm{~cm}\end{array}$ & $\begin{array}{c}12 \times 5 \mathrm{~cm} \\
\sim 45 \times 16 \mathrm{~cm}\end{array}$ \\
\hline $\begin{array}{l}\text { 血管柄付骨 · } \\
\text { 皮弁移植症例 }\end{array}$ & 5 例 & 6 例 & 1 例 & 3 例 & 0 例 \\
\hline 年齢 & $3 \sim 87$ 歳 & $5 \sim 57$ 歳 & 9 73 歳 & $15 \sim 50$ 歳 & $9 \sim 50$ 歳 \\
\hline
\end{tabular}


管付 flap は，血管吻合を必要とするために有茎の flap に比較し，安全性が低いし，Recipient 側の血 管の状態の確認も必要である. 私達は図 I のような皮 虐欠損に対して順向性，逆行性皮弁で骨，神経血管露 出部を被う事にしている。しかし，損傷の状態で有茎 の Peroneal flapが挙上できないとき, Recipient 側の血管造影をして，吻合血管を確認し，第 1 選択と して表 I のようにflap の挙上が容易で血管径が大き く, 血管の解剖学的異常が少ない時 Scapular flap を用いる事にしている. $5 \mathrm{~cm}$ 以上の脛骨の骨欠損， 皮膚欠損に対しては，血管柄付腓骨を用いる事にして いる，皮䖉欠損が下肢全体，又は足部までと著しく広 範囲な場合, Latissimus dorsi flap を用いる事に している. 最も大きい flap は $45 \mathrm{~cm} \times 16 \mathrm{~cm}$ であった. 遊離血管柄付き flap を用いる場合，私たちは，Recipient 側の吻合状態に特に気を使う. Peroneal flap （遊離）施行のため 1 週間前に Peronealortery, vein の確認のため手術を施行した事もある.
ま と め

(1)下腿，足部の皮膚欠損 ${ }^{2)} に$ 対して，有茎 Peroneal flap 25 例, 遊離の Peroneal flap 19例, Scapular flap 8 例, Groin flap 9 例, Latissimus dorsi flap 5 例を施行した.

(2)Rotation flap などの局所皮弁で被えないとき 有茎の Peroneal flap で骨, 神経, 血管露出部を被 い，他は全層，又は分層植皮をしている，有茎の Peroneal flap が利用できないとき, Scapular flap を 使用し，下腿全体におよぶ皮膚欠損には Latissimus dorsi flap を利用している.

\section{参 考 文 献}

1) Nakashima Hidechika, et al.: Free Peroneal Flap for Wide Skin Defects of the Foot and Volar Scar Contracture of the Hand. Journal of Rconstructive Microsurgery, 3 : 105-111, 1987.

2）中島英親ら：有茎血管付皮弁と遊離皮弁による足部皮 虐欠損に対する治療経験。中部整災誌。 $35: 785-786$, 1992. 